\title{
Comparison Between Immunohistochemical Expression of Cyclin D1 and p21 and Histological Malignancy Graduation of Oral Squamous Cell Carcinomas
}

\author{
Adriana da Costa NEVES ${ }^{1}$ \\ Ricardo Alves MESQUITA ${ }^{2}$ \\ Moacir Domingos NOVELLI ${ }^{1}$ \\ Edna TODDAI ${ }^{1}$ \\ Suzana Orsini Machado De SOUSA $^{1}$ \\ ${ }^{1}$ Discipline of Oral Pathology, School of Dentistry, University of São Paulo, São Paulo, SP, Brazil \\ ${ }^{2}$ Discipline of Oral Pathology, School of Dentistry, University of Minas Gerais, Belo Horizonte, MG, Brazil
}

\begin{abstract}
The objective of the present study was to correlate the expression of cyclin D1 with the expression of p21 in 28 cases of oral squamous cell carcinoma (OSCC), as well as to compare the expression of both with a histological graduation of this neoplasm. Immunohistochemistry was used to obtain the expression of cyclin D1 and $\mathrm{p} 21$. The results of statistical analysis showed no correlation between the expression of cyclin D1 and p21. Also, there was no correlation between the mean numbers of cyclin D1 positive nuclei and p21 positive nuclei and the histological scores of malignancy. However, the marked expression of cyclin D1 in high-grade tumors supports its role in proliferative activity. In contrast, p21 seems unable to arrest tumor progression in OSCC.
\end{abstract}

Key Words: cyclin D1, p21, oral squamous cell carcinoma.

\section{INTRODUCTION}

Cancer is a disease caused by genetic alterations, most of them involved in the control of cell proliferation. These genetic alterations can affect the synthesis of proteins, which is frequently disturbed in neoplastic cells $(1,2)$.

Cyclins are a group of proteins responsible for the activation of the main cell division transitional points. Cyclins regulate the activity of kinases, which for this reason have been named cyclin-dependentkinases (Cdks). The activation of specific cyclin-Cdk complex results in a cascade of protein phosphorylations that are required for passage through a specific stage of cell cycle. Cyclin D1 is believed to control cell cycle transit from G1 into S phase, by binding Cdks 4 and $6(1-6)$.

Since cyclin D1 acts stimulating the cell cycle, much research has been carried out in order to deter- mine whether alterations in the synthesis of this protein are related to carcinogenesis, and to confirm the use of cyclin D1 as a biologic marker, being useful to predict the course of malignant neoplasm (7-9).

Research studies have correlated the immunohistochemical expression of cyclin D1 with a more aggressive behavior of squamous cell carcinomas of the head and neck (SCCHN), and with a shorter overall survival $(7,9,10)$. Other studies have tried to associate the expression of this protein with histological parameters. Lam et al. (8) observed that oral squamous cell carcinomas (OSCC) with low and intermediate grades of differentiation had a higher expression of cyclin D1 when compared to tumors with a high-grade of differentiation.

p21 is a product of a suppressor gene and acts as an inhibitor of complexes formed by cyclins $\mathrm{D}, \mathrm{E}$ and $\mathrm{A}$, and their respective Cdks $(1,2)$. The action of $\mathrm{p} 21$ is mainly induced by p53. Once activated, p53 will induce

Correspondence: Dra. Adriana da Costa Neves, Disciplina de Patologia Bucal, Faculdade de Odontologia, Universidade de São Paulo, Av. Prof. Lineu Prestes 2227, 05508-900 São Paulo, SP, Brasil. Tel/Fax: +55-11-3091-7902. e-mail: neves@usp.br 
programmed cell death, through bax or cell cycle arrest through p21 (11).

In contrast to cyclin D1, few studies have correlated the immunohistochemical expression of p21 with clinical and histological parameters of SCCHN. Agarwal et al. (12), studying OSCC, observed that immunohistochemical expression of p21 was associated with tumor differentiation.

A few investigations have concentrated on correlating the immunohistochemical expression of cyclin D1 with the expression of p21. Van Oijen et al. (13), studying squamous cell carcinomas and epithelial dysplasias of the head and neck, observed a positive correlation between expression of cyclin D1 and p21.

Thus, the aim of this study was to correlate the immunohistochemical expression of cyclin D1 with the expression of p21 in OSCC, as well as to compare the expression of both with the histological malignancy graduation of this neoplasm.

\section{MATERIAL AND METHODS}

Specimens from 28 cases of OSCC, diagnosed in the Department of Oral Pathology, School of Dentistry, University of São Paulo, were evaluated. The age, sex, and anatomic localization were collected from the clinical records of patients (Table 1).

\section{Immunohistochemistry}

Immunohistochemical staining was performed using the streptavidin-biotin method. Briefly, the 3- $\mu \mathrm{m}$ sections from the paraffin-embedded materials were dewaxed with xylene, hydrated through graded alcohols and rehydrated in water. For p21, the sections were placed in citrate buffer $(\mathrm{pH}=6.0,10 \mathrm{mM})$ and microwaved 3 times for 5 min each. For cyclin D1, the sections were placed in EDTA $(\mathrm{pH}=8.0,1 \mathrm{mM})$ in a steamer for $20 \mathrm{~min}$ at $95^{\circ} \mathrm{C}$. The sections were placed in $0.6 \%$ hydrogen peroxide in methanol for $10 \mathrm{~min}$ to block endogenous peroxidase activity.

The sections were incubated with the primary antibodies, diluted in a solution of TRIS $(\mathrm{pH}=7.4)$, and $1 \%$ of bovine albumin (BSA, Biotest S/A, São Paulo, Brazil). Monoclonal antibody against cyclin D1 (1:100, clone DCS-6, Dako Corporation, Golstrup, Denmark) was applied over the sections for $2 \mathrm{~h}$ at $37^{\circ} \mathrm{C}$. Monoclonal antibody against p21 (1:30, clone SX118, Dako
Corporation) was applied over the sections for $18 \mathrm{~h}$ at $4^{\circ} \mathrm{C}$. This was followed by the use of the StreptavidinBiotin Kit (Dako Corporation, KO-690). Sections were then incubated in diamine benzidine solution $(0.3 \%)$ for $3 \mathrm{~min}$, and then counter-stained with Mayer's hematoxylin.

As positive controls, we used sections of squamous cell carcinomas that were strongly positive for cyclin D1 and p21. As negative controls, we used the same sections, which were used as positive controls, replacing the primary antibody with buffer solution.

Table 1. Clinicopathological characteristics of tumors with low (1-2.5) and high (2.6-4.0) scores of malignancy.

\begin{tabular}{|c|c|c|c|c|c|c|}
\hline Case & Gender & Age & Location & HMGS & Cyclin & p21 \\
\hline 1 & M & 69 & Lip & 1.4 & 3 & 0 \\
\hline 2 & $\mathrm{~F}$ & 77 & Buccal mucosa & 1.6 & 0 & 0 \\
\hline 3 & M & 70 & Floor of mouth & 1.8 & 2 & 4 \\
\hline 4 & M & 42 & Alveolar ridge & 1.8 & 3 & 2 \\
\hline 5 & M & 54 & Alveolar ridge & 1.8 & 5 & 3 \\
\hline 6 & M & & Floor of mouth & 2.0 & 0 & 0 \\
\hline 7 & M & 40 & Tongue & 2.2 & 4 & 5 \\
\hline 8 & M & 51 & Alveolar ridge & 2.2 & 4 & 3 \\
\hline 9 & M & 68 & Alveolar ridge & 2.2 & 1 & 5 \\
\hline 10 & M & & Soft palate & 2.2 & 1 & 4 \\
\hline 11 & M & 50 & Tongue and gingiva & 2.2 & 4 & 2 \\
\hline 12 & $\mathrm{~F}$ & 83 & Alveolar ridge & 2.2 & 1 & 0 \\
\hline 13 & M & 55 & Hard Palate & 2.2 & 3 & 5 \\
\hline 14 & M & 55 & Tongue & 2.4 & 0 & 1 \\
\hline 15 & M & 46 & Alveolar ridge & 2.8 & 5 & 1 \\
\hline 16 & M & 42 & Floor of mouth & 2.8 & 0 & 3 \\
\hline 17 & M & 54 & Soft palate & 2.8 & 3 & 2 \\
\hline 18 & M & 70 & Buccal mucosa & 2.8 & 4 & 3 \\
\hline 19 & M & 43 & Floor of mouth & 2.8 & 2 & 5 \\
\hline 20 & M & 59 & Floor of mouth & 3.0 & 1 & 3 \\
\hline 21 & $\mathrm{~F}$ & 44 & Tongue & 3.0 & 5 & 4 \\
\hline 22 & M & 54 & Soft palate & 3.0 & 5 & 4 \\
\hline 23 & M & 45 & Tongue & 3.0 & 4 & 3 \\
\hline 24 & M & 64 & Floor of mouth & 3.0 & 4 & 0 \\
\hline 25 & $\mathrm{~F}$ & 58 & Tongue & 3.2 & 3 & 4 \\
\hline 26 & $\mathrm{~F}$ & 76 & Hard palate & 3.4 & 2 & 0 \\
\hline 27 & M & 62 & Alveolar ridge & 3.4 & 4 & 4 \\
\hline 28 & $\mathrm{M}$ & 48 & $\begin{array}{c}\text { Floor of mouth and } \\
\text { gingiva }\end{array}$ & 3.6 & 2 & 3 \\
\hline
\end{tabular}

$\mathrm{M}=$ male $; \mathrm{F}=$ female HMGS = histological malignancy grading system. Cyclin D1 and p21 expression according to the scores of positive cells: $0=$ less than $1 \%$ of positive cells, $1=1-10 \%$ of positive cells, $2=10-20 \%$ of positive cells, $3=20-30 \%$ of positive cells, $4=30-40 \%$ of positive cells, $5=$ more than $40 \%$ of positive cells. 
The slides stained by hematoxylin and eosin were classified according to the histological malignancy grading system proposed by Anneroth et al. in 1987 (14), modified by Araújo et al. (15). Histological graduation was performed by two independent observers. Five morphologic parameters were evaluated: degree of keratinization, nuclear polymorphism, number of mitoses, pattern of invasion, and lympho-plasmocytic infiltration. Scores from 1 to 4 were assigned to each parameter. The mean of total malignancy score value was achieved by the sum of the scores attributed to each parameter divided by the number of parameters used. The mean total malignancy score values were divided into two groups with low (within the mean score range 1.0-2.5 points) and high (within the mean score range 2.6-4.0 points) scoring.

\section{Quantitative Analysis}

The sections stained by immunohistochemistry were evaluated using a light microscope, with 400X magnification. The images were transferred to a computer and the positive nuclei for cyclin D1 and p21, which were individualized by the Software ImagelabSoftium ${ }^{\circledR}$, were counted. The positive nuclei were counted in 1000 cells. Fields were chosen randomly.

For statistical analysis, the immunohistochemical expression was considered over the absolute percentage of cyclin D1 and $\mathrm{p} 21$ positive cells, which was obtained for each section analyzed.

The expression of cyclin D1 and $\mathrm{p} 21$ were graded according to the scores: $0=$ less than $1 \%$ of positive cells, $1=1-10 \%$ of positive cells, $2=10-20 \%$ of positive cells, $3=20-30 \%$ of positive cells, $4=30-40 \%$ of positive cells, $5=$ more than $40 \%$ of positive cells.

\section{Statistical Analysis}

Data obtained from the expression of cyclin D1 and p21 were submitted to analysis of variance, in order to verify a possible difference in the expression of cyclin D1 and p21 between the two groups of OSCC studied. In order to determine if there was any correlation between the expression of cyclin D1 and p21, Pearson's correlation test was applied.

For statistical analysis, the software MINITAB $12.1^{\circledR}$ was used. Differences were considered statistically significant when $\mathrm{P}$ was less than 0.05 .

\section{RESULTS}

The scores of histological graduation and the scores of positive cells attributed to each tumor are shown in Table 1. Fourteen tumors were graded as low malignancy and 14 were graded as high malignancy. The location, gender, and age in each case can also be seen in Table 1.

Immunohistochemical expression of cyclin D1 and p21 varied in proportion of stained cells and the distribution of positive cells was heterogeneous between cancer nests.

Cyclin D1 was expressed mainly in peripheral layers of tumor islands and strands (Figure1A). How-
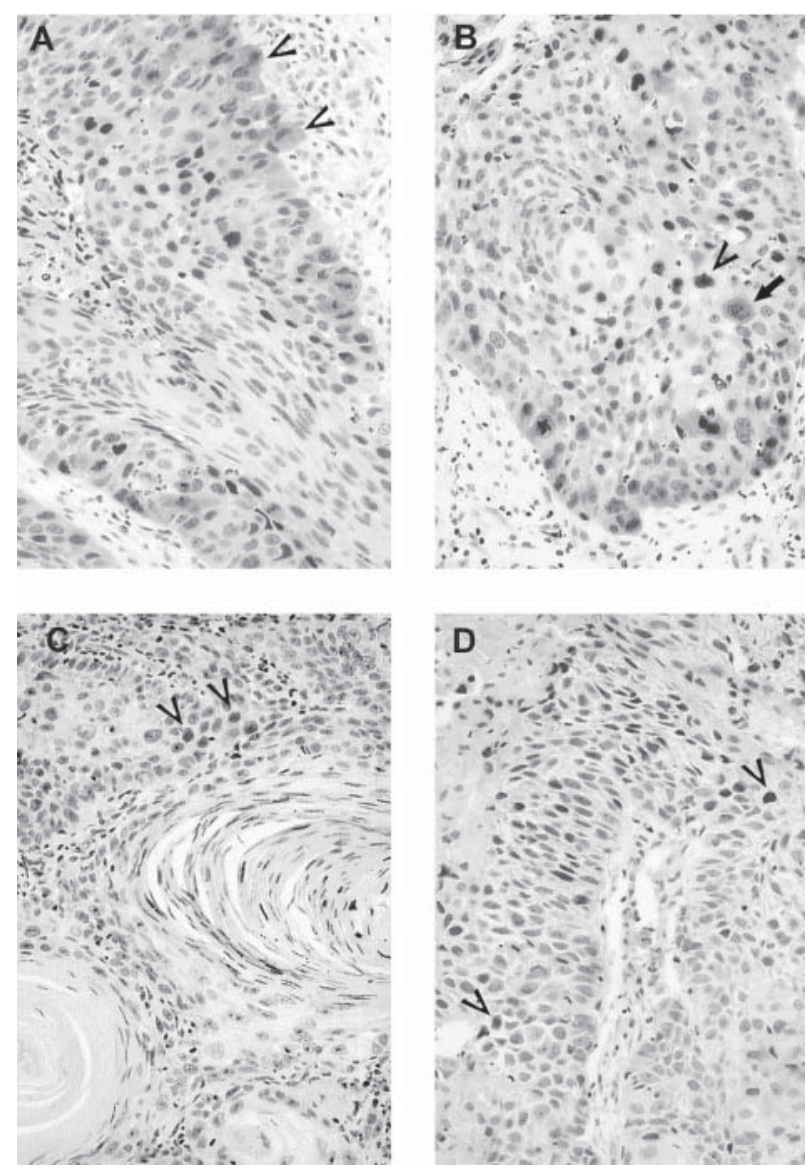

Figure 1. Immunohistochemical expression of cyclin D1 and p21 in oral squamous cell carcinomas. $A$ : Cyclin $\mathrm{D} 1$ expression in peripheral layers of tumor islands and strands (arrowheads). $B$ : Positive nuclear staining for cyclin D1 (arrowhead), cell exhibiting mitosis negative for cyclin D1 staining (arrow). $C$ : p21 expression in well-differentiated cells (arrowheads). D: p21 expression in central layers of tumor islands and strands (arrowheads). Original magnification: 89X. 
ever, in some samples, positive cells were distributed in the central areas of tumor islands. In some cases, we observed positive cells close to pearls of keratinization. Cells exhibiting mitosis did not show nuclear staining for cyclin D1 (Figure 1B).

Twenty-four $(85.7 \%)$ of the 28 cases of OSCC were positive for cyclin D1. Among the four cases that were negative, only one was scored as high malignancy (Figures 2 and 3). The group of tumors with low scores of malignancy presented high frequency of samples, in which the percentage of cyclin D1 positive cells ranged from 0 to $10 \%$, when compared to the group of tumors with high scores of malignancy (Figures 2 and 3).

In the group of tumors with low scores of malignancy, the percentage of cyclin D1 positive cells ranged

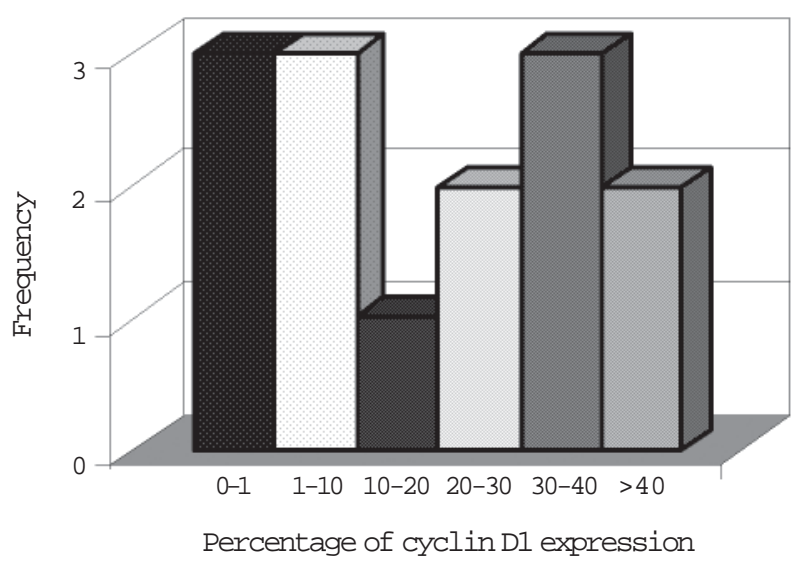

Figure 2. Expression of cyclin D1 in tumors with low scores of malignancy.

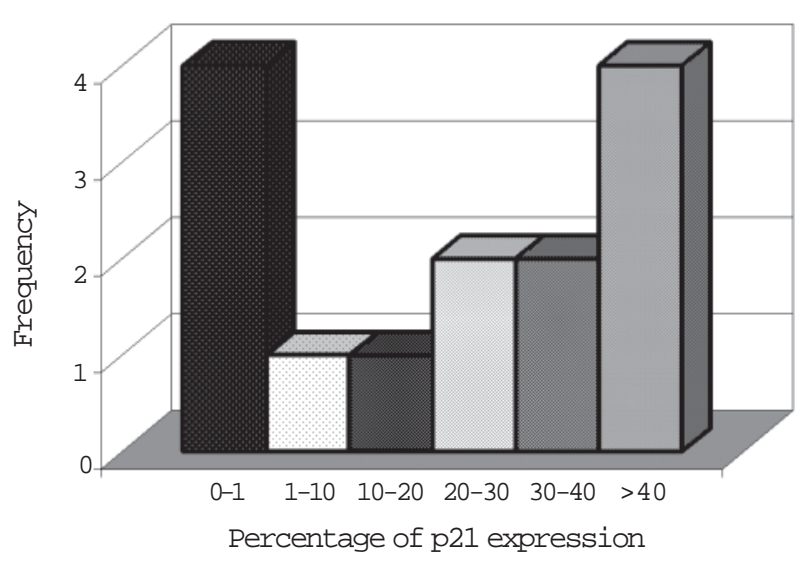

Figure 4. Expression of p21 in tumors with low scores of malignancy. from 0 to $47 \%$, and the mean expression in this group was $19.3 \%$. In the group of tumors with high scores of malignancy, the percentage of cyclin D1 positive cells ranged from 0 to $48.1 \%$, and the mean expression in this group was $26 \%$. Analysis of variance did not show statistically significant differences between the two groups of OSCC studied ( $>0.05$ ).

p21 was expressed mainly in suprabasal and central layers of tumor islands and strands (Figure1D). In most cases, we observed p21 expression in welldifferentiated cells, presenting keratinization (Figure 1C). However, in some samples, positive cells were distributed in the peripheral layers of tumor islands. Cells exhibiting mitosis did not demonstrate nuclear staining for $\mathrm{p} 21$.

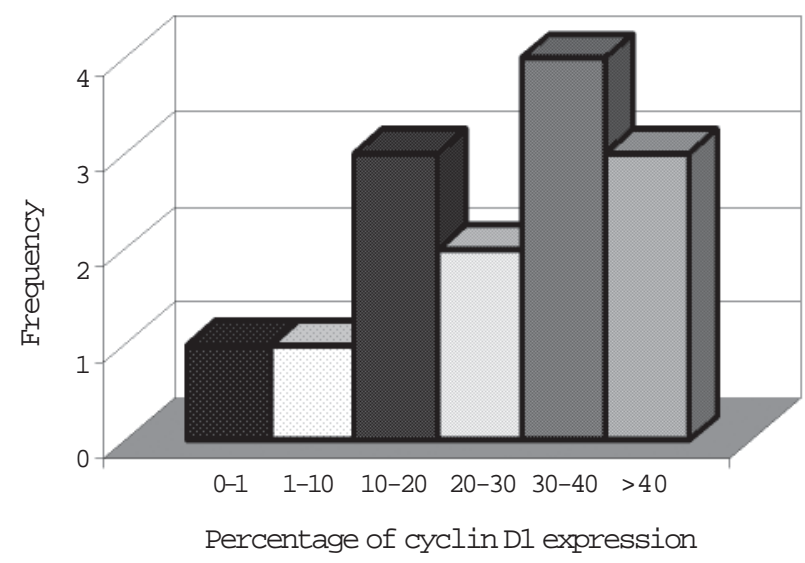

Figure 3. Expression of cyclin D1 in tumors with high scores of malignancy.

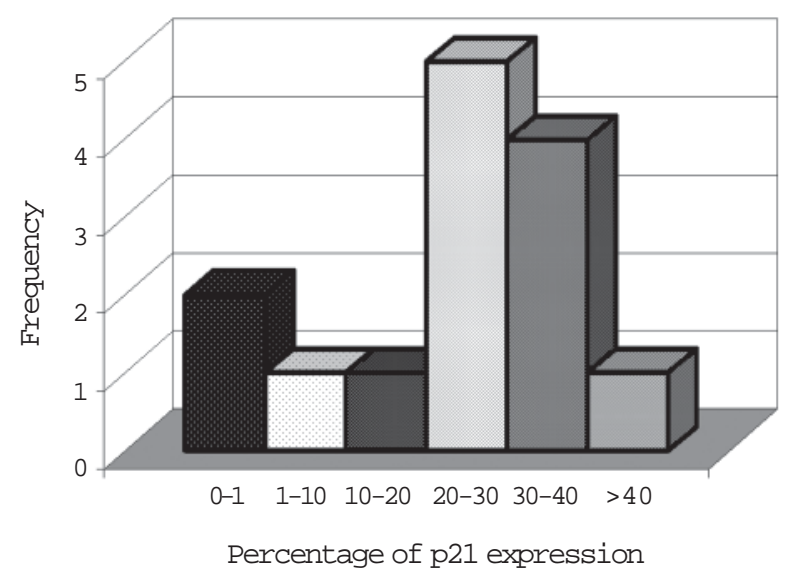

Figure 5. Expression of p21 in tumors with high scores of malignancy. 
Twenty-two (78.6\%) of the 28 cases of OSCC were positive for $\mathrm{p} 21$. Of the six negative cases, two were graded as high malignancy scoring, and four were graded as low malignancy scoring (Figures 4 and 5).

In the group of tumors with low scores of malignancy, the percentage of $\mathrm{p} 21$ positive cells ranged from 0 to $53.3 \%$, and the mean expression in this group was $23.8 \%$. In the group of tumors with high scores of malignancy, the percentage of $\mathrm{p} 21$ positive cells ranged from 0 to $47.5 \%$, and the mean expression in this group was $23.1 \%$. Analysis of variance did not show statistically significant differences between the groups of OSCC studied ( $\mathrm{p}>0.05)$.

Pearson's correlation test did not show any correlation between expression of cyclin D1 and p21 $(\mathrm{r}=0.181)$.

\section{DISCUSSION}

The search for new indicators of prognosis of tumors is important, and since cyclin D1 and p21 are both involved in the control of cell cycle, understanding the expression of these proteins in malignant neoplasms is essential.

The present study demonstrated that cyclin D1 was expressed in the outer layers of the islands and cords of tumor cells in the OSCC studied. This finding was expected since cyclin D1 is an activator of the cell proliferation cycle, and peripheral cells are those supposed to be the most proliferative and invasive ones. The absence of cyclin D1 in mitotic cells is probably due to the inactivation of this protein at the end of $S$ phase, and to its short half-life (16).

Statistical analysis showed no differences between the expression of cyclin D1 in low- and highgrade OSCC, although a tendency of higher expression towards high-grade OSCC was noted since medium expression of the protein was a little bit higher. Moreover, low-grade OSCC were more often negative for cyclin D1 expression or presented percentages lower than $10 \%$.

The higher expression of cyclin D1 in highgrade tumors might be explained by the fact that alterations in cyclin $\mathrm{D} 1$ are related to an intense proliferative activity and invasiveness capacity of the lesions (8-10). In contrast, the absence of cyclin D1 can be related to the deregulation of other proteins in the cycle.

In most cases, p21 was expressed in supra-basal and central cells of the tumor islands and cords, especially in the more differentiated or mature cells. This finding was expected since a role for $\mathrm{p} 21$ as an inducer of cell differentiation has been shown $(17,18)$. In some cases, p21 was also expressed in basal cells of islands and cords. In these cases, a co-expression of cyclin D1 and p21 was seen. Probably, in these cells, the expression of cyclin D1 nullifies the action of p21 in inhibiting cell cycle (13).

Results obtained with analysis of variance showed no statistically significant differences between expression of p21 in high- and low-grade carcinomas. This result may suggest that the action of p21 as a tumor suppressor comes before its action in inducing cell differentiation (18). Probably, in the cases seen, p21 expression was related to its action as tumor suppressor. Alterations in the p21 gene are unlikely to be occurring, as seen previously by some studies in the literature (19).

If we take into account the group classified in the present study as low-grade malignancy, there were more cases in which p21 was not expressed, when compared to high-grade tumors. (Figures 4 and 5). Possibly, in low-grade tumors, p21 initiating pathways are not activated and other molecules that negatively control cell cycle are acting. The absence of p21 in normal mucosa as shown in the literature corroborates this view (12). On the other hand, in high-grade tumors where p21 was absent, genetic disturbances in p53 expression may have caused the inactivation of $\mathrm{p} 21$ pathway. The expression of $\mathrm{p} 21$ in the oral carcinomas studied suggests that $\mathrm{p} 21$ by itself seems unable to arrest tumor progression.

No correlation was found between $\mathrm{p} 21$ and cyclin D1 expression in the carcinomas studied. This fact could be due to the expression of each one in different cell populations, as previously described by Van Oijen et al. (13). To confirm this information, double-labeling studies are needed.

In summary, our data showed no correlation between cyclin D1 and p21. However, the marked expression of cyclin D1 in high-grade tumors supports its role in proliferative activity. In contrast, p21 seems unable to arrest tumor progression in OSCC.

\section{RESUMO}

A proposição desse trabalho foi correlacionar a expressão das 
proteínas ciclina D1 e p21 em 28 casos de carcinomas epidermóides de boca, e comparar a expressão das mesmas com os escores histológicos de malignidade atribuídos para essa neoplasia. A expressão das proteínas foi obtida através da utilização da técnica imuno-histoquímica da StreptoavidinaBiotina. A análise estatística revelou não haver correlação entre a expressão da ciclina D1 e do p21 nos carcinomas epidermóides estudados. Não houve correlação entre os números médios de núcleos ciclina D1 e p21 positivos e os escores histológicos de malignidade atribuídos para os carcinomas estudados. Entretanto, houve uma ligeira tendência de maior expressão da ciclina D1 nos tumores de alto grau de malignidade, isso provavelmente ocorreu devido a maior atividade proliferativa desses tumores. Já a alta expressão encontrada para o p21 nos tumores estudados sugere que ele sozinho parece ser um ineficiente supressor tumoral.

\section{REFERENCES}

1. Goodger NM, Ganon J, Hunt T, Morgan PR. Cell cycle regulatory proteins - an overview with relevance to oral cancer. Oral Oncol 1997;33:61-73.

2. Michalides RJ. Cell cycle regulators: mechanisms and their role in aetiology, prognosis, and treatment of cancer. J Clin Pathol 1999;52:555-568.

3. Hall PA, Coates PJ. Assessment of cell proliferation in pathology - what next? Histopathology 1995;26:105-112.

4. Jacks T, Weinberg RA. The expanding role of cell cycle regulators. Science 1998;280:1035-1036.

5. Nasmyth K. Viewpoint: putting the cell cycle in order. Science 1996;274:1643-1645.

6. Nurse P. Ordering $\mathrm{S}$ phase and $\mathrm{M}$ phase in the cell cycle. Cell 1994;79:547-550.

7. Kuo MY, Lin CY, Chiang CP. Expression of cyclin D1 is correlated with poor prognosis in patients with areca quid chewingrelated oral squamous cell carcinomas in Taiwan. J Oral Pathol Med 1999;28:165-169.

8. Lam KY, Ng IO, Yuen APW, Kwong DLW, Wei W. Cyclin D1 expression in oral squamous cell carcinomas: clinicopathological relevance and correlation with p53 expression. J Oral Pathol Med 2000;29:167-172.

9. Michalides RJ, Van Veelen N, Kristel PMP, Hart AAM, Loftus BM, Hilgers FJM, Balm AJM. Overexpression of cyclin D1 indicates poor prognosis in squamous cell carcinomas of the head and neck. Arch Otolaryngol Head Neck Surg 1997;123:497-502.

10. Staibano S, Mignogna MD, Muzio LL, Di Alberti L, Natale ED, Lucariello A, Mezza E, Bucci E, De Rosa G. Overexpression of cyclin D1, bcl-2, and bax proteins proliferating cell nuclear antigen (PCNA), and DNA-ploidy in squamous cell carcinomas of the oral cavity. Hum Pathol 1998;29:1189-1194.

11. Lane DP. Cancer. A death in the life of p53. Nature 1993;362:786787.

12. Agarwal S, Mathur M, Shukla NK, Ralhan R. Expression of cyclin dependent kinase inhibitor P21 Waf1/Cip1 in premalignant and malignant oral lesion: relationship with p53 status. Oral Oncol 1998:34:353-360.

13. Van Oijen MG, Tilanus MGJ, Medema RH, Slootweg PJ. Expression of p21 (Waf1/Cip1) in head and neck cancer in relation to proliferation, differentiation, p-53 status and cyclin D1 expression. J Oral Pathol Med 1998;27:367-375.

14. Anneroth G, Batsakis J, Luna M. Review of the literature and a recommended system of malignancy grading in squamous cell carcinomas. Scand J Dent Res 1987;95:229-249.

15. Araújo VC, Pinto Jr DS, Sousa SOM, Nunes FD, Araújo NS. Expression of vimentin in oral squamous cell carcinoma biopsy tissues. Eur Arch Otorhinolaryngol 1993;250:105-109.

16. Hunter T, Pines J. Cyclins and cancer. II: cyclin D and CDK inhibitors come of age. Cell 1994;79:573-582.

17. $\mathrm{Ng} \mathrm{IO,} \mathrm{Lam} \mathrm{KY,} \mathrm{Ng} \mathrm{M,} \mathrm{Regezi} \mathrm{JA.} \mathrm{Expression} \mathrm{of} \mathrm{p21/Waf1} \mathrm{in}$ oral squamous cell carcinomas - correlation with p53 and mdm2 and cellular proliferation index. Oral Oncol 1999;35:63-69.

18. Steinman RA, Hoffman B, Iro A, Guillouf C, Libermann, DA, ElHousenini ME. Induction of p21 (WAF-1/CIP) during differentiation. Oncogene 1994;9:3389-3396.

19. Shiohara M, El-Deiry WS, Wada M, Nakamaki T, Tekeuchi S, Yang R, Chen DL, Vogelstein B, Koeffler HP. Absence of WAF1 mutations in a variety of human malignancies. Blood 1994;84:3781-3784. 